\title{
DIMITRI BRATKIN
}

\section{D.A. Chwolson as an Expert Witness and Student of Abraham Geiger: Three Chapters from a Scholarly Biography}

\author{
DOI: https://doi.org/10.22394/2311-3448-2019-6-1-65-85
}

Dimitri Bratkin - Department of the Philosophy of Religion and Religious Studies, St. Petersburg State University (Russian Federation). bratkin@yandex.ru

This article is based on unpublished sources from St. Petersburg archives (the Manuscript Department of the Russian National Library, the St. Petersburg Branch of the Archive of the Russian Academy, and the Russian State Historical Archive). It explores the forms and methods of Daniel Chwolson's (1819-1911) work on academic protection for the Jewish minority. Apart from his well-known effort to refute blood libel accusations that spanned five decades (1861-1911), Chwolson's activities on behalf of Jews included less obvious projects and approaches. For instance, he attempted (unsuccessfully) to establish an "associate professorship for Judaic Studies" at St. Petersburg University in 1896-97, which in due course would give birth to the "Academy of Baron Günzburg." Less apparent but equally important is his work in refuting anti-Jewish theological presuppositions; in this he followed in the footsteps of his admired teacher, Abraham Geiger, and the methodologies of Wissenschaft des Judentums. In so doing, Chwolson argued against Christian confessional distortions of Judaism. His firm insistence that early Jewish sources be used in the

\footnotetext{
This research has been completed with the support of grant RNF No. 16-18-10o83, "Izuchenie religii $\mathrm{v}$ sotsiokul'turnom kontekste epokhi: Istoriia religiovedeniia i intellektual'naia istoriia Rossii XIX-pervoi poloviny XX vv." [The study of religion in the socio-cultural context of the era: The history of religious studies and the intellectual history of Russia in the 19th and the first half of the 2oth centuries].
} 
study of the New Testament and early Christianity anticipated a turn that would become mainstream in the latter half of the 2oth century.

Keywords: Daniel Chwolson, Khvolson, Khvol'son, minority, Judaism, Early Christianity, Pharisees, history of scholarship, Jewish Studies, Wissenschaft des Judentums.

$\square$ ANIEL A. Chwolson'1 (Daniil Avraamovich Khvol'son) (18191911) is known in the history of humanities in Russia as a Jewish child prodigy, a former yeshiva student who studied languages (other than Hebrew and Aramaic) and other secular subjects through self- education, who managed to become a student of Abraham Geiger and a personal protégé of Avraam S. Norov; following his conversion to the state church, he held the chair of Hebrew and Syriac philology at St. Petersburg University. Chwolson was in effect the founder of the St. Petersburg Semitological school, of Hebrew paleography and Semitic epigraphy as a field of systematic research in Russia and, therefore, an active participant in the discussions over the authenticity of certain manuscripts and inscriptions collected by Avraam S. Firkovich. Chwolson himself was also one of the first to collect and comment on Eastern sources on the history of medieval Eastern Europe and Ancient Rus, and to acquire a vast collection of Hebrew books and early printed books that in due course became part of the Academic collection. Daniel Chwolson was part of the social and political history of Russia in the 19th century as the most assiduous combatant against the blood libel. It is hardly possible to refer to this scholar as "little-known," much less as "forgotten," but beyond this discrete, albeit broad, set of contexts, Daniel Chwolson certainly remains an understudied figure. Suffice it to say that a detailed foundational biography of the scholar, written from the standpoint of modern knowledge of him and his era, has still not been published, which is striking against the background of Russia's flourishing Judaic studies and especially of the study of the history of Russian-Jewish intellectual life of the 19th and 20th centuries. Such a biography

1. Despite the present tendency, I am systematically using the German-style transliteration "Chwolson" (instead of the English "Khvol'son") since it was the Latinization favored and authorized by the bearer himself and the members of the same family in their lifetime. The variant "Khvol'son" is used in the bibliography only, to indicate the Cyrillic original. 
is sorely needed, and the main research task would consist not only of assessing Daniel Chwolson's contribution to those fields of scholarship in which he was engaged as a Russian academic professional working among his peers, but also to the wider social and cultural context, including the European and world contexts. As preparatory material toward this biography, I offer to the readers three interrelated chapters; here Daniel Chwolson appears in three roles, which complemented his position as a professor (ordinarnyi professor) of the capital's university - in other words: (1) as a public expert who addressed the wider lay public, (2) as a founding figure of his scholarship, who formulated a new agenda for the discipline of which he was the doyen, and finally, (3) a professional in the particular field of his scholarly expertise.

\section{The public expert struggling against blood libel}

Chwolson's most famous work on this topic was a small booklet titled "On Certain Medieval Accusations against the Jews," published in 1861 (Khvol'son 1861). The author himself in the second edition of the same book explained the circumstances that demanded its publication at the behest of the faculty of Oriental languages of St. Petersburg University:

[In 1852-53 - D.B.] many Jews, mostly soldiers, were accused of killing two Christian children in Saratov, with the intention of using their blood for religious purposes. In relation to this, a special commission was established under the Ministry of Internal Affairs by the tsar's order and was charged with a dual mandate. First, it was to examine the Jewish books, manuscripts, and letters seized from the accused in large numbers, whether information would be found in them that could serve as proof of the correctness of the accusation. The second assignment of the commission was to investigate the question: do Jews in gener$\mathrm{al}$, or does some sect among them, use Christian blood for any religious or other purposes of any kind? [. . . The members of the commission were Archpriest Gerasim Petrovich Pavsky and Fedor Fedorovich Sidonsky; in addition, a professor of the biblical Hebrew language at the local [St. Petersburg - D.B.] theological academy, Vasily Andreevich Levison, and I myself. The first two members of the commission stated that they understood only the biblical language and were not familiar with the post-biblical literature of the Jews and that therefore they were not in a position to read the abovementioned books. For this reason, exam- 
ination of the confiscated books, manuscripts, and letters was entrusted to Levison and me. [. . .] My response, in terms favorable to the Jews, filled about 100 pages: [I] placed a detailed analysis of the Saratov case at the end of it. [. . .] Later I reworked my response, supplemented it significantly, and published it first in Biblioteka dlia chteniia ${ }^{2}$ and then as a separate edition. (Khvol'son 1880a, vii-ix)

Later an abridged version of this report was published, with censorial permission for printing dated October 8, 1879 (Khvol'son 1879). This date suggests a story behind it. In March 1879 a number of Jews were indicted on charges of murdering a Georgian Christian girl. The defendants were acquitted by the local court of Kutaisi. The prosecution appealed to the supreme court of Tiflis court chamber with the date of proceedings being set for April 1880. In between, certain periodicals in St. Petersburg became involved in the matter and republished the older anti-Jewish texts in support of the blood libel. That caused a considerable revival of blood libel literary publications. For instance, the topical accusation of child torture by a Jew was referred to, rather sympathetically, by Fyodor Dostoyevsky in his novel The Brothers Karamazov, which was published serially at the time. Chwolson's involvement included a number of literary publications. First, the abridgement of his 1861 monograph was published in October 1879. The second, expanded and improved edition of "Certain Medieval Accusations" was completed by Chwolson in January 1880 and formally approved by the Oriental Faculty of St. Petersburg University on February 4 of that year (Khvol'son 1880) to be followed by yet another little book. The brochure "On the Supposed Insularity" of the Jews (the censor's permission was dated February 21, 1880) was also probably published for the same purpose (Khvol'son 1880).

It should be noted that by the turn of the 2oth century this story had become one of the key points of Chwolson's biographical narrative. In 1900, David G. Günzburg (Gintsburg) mentioned this episode in his jubilee articles dedicated to Chwolson's eightieth birthday:

The Kutaisi trial prompted the dissemination of 10,000 copies of his booklet "Do the Jews Use Christian Blood?," profound in its brevity, and then also the appearance of the landmark work "On Certain Medieval

2. Biblioteka dlia chteniia - a Russian journal, the title of which means "Library for reading" - Trans. 
Accusations against the Jews" (1880) in a revised form and twice the original length. Not content [to use only] his pen, Dan[iil] Abr[amovich, i.e., Chwolson - D.B.], in a long audience with the then august governor of the Caucasus, Grand Duke Mikhail Nikolaevich, managed to dispel all possible suspicions concerning ritual murder. (Gintsburg [Günzburg] 1900, column 13)

Further, Günzburg quotes in his own Russian phrasing what I believe to be the record of an oral history from Chwolson himself (OR RNB, f. 183, Gintsburg D.G., ed. khr. 51): ${ }^{3}$

The rabbis blessed the name of Dan[iil] Abr[amovich]; and when he proceeded to Kutaisi from Tiflis, to which the most interesting of all archaeological congresses had drawn him in 1881, he learned from the judges that they derived their own belief in the innocence of the accused from his ardent defense of the Jewish tribe. The marshal of the nobility brought him to the synagogue past Jews standing all along the road; the synagogue was illuminated, the holy ark was opened, and a solemn $\mathrm{Mi}$ Sheberach ${ }^{4}$ was proclaimed to Daniil Abramovich. A venerable rabbi, of splendid appearance and truly biblical bearing, gave a heartfelt speech in the Hebrew language, another rabbi spoke in Georgian, during which the marshal served as interpreter, and then the address was presented. (Gintsburg [Günzburg] 1900)

In 1901, an authorized German translation of "[On] Certain Medieval Accusations" was published (Chwolson 1901), 5 and, finally, the brochure "Do the Jews Use Christian Blood?" was reissued after Chwolson's death in 1912 (Khvol'son 1912).

It is less known that throughout his service at the St. Petersburg Catholic Theological Academy, Daniel Chwolson spoke annually to the students, the future Catholic priests of the Russian part of Poland and

3. An undated note in German. The text of the following quotation below reproduces the text on list $4 \mathrm{ob}$. [sheet or page 4 , obverse] of the document with several changes. On the oral history behind the published jubilee eulogy in Voskhod, see my forthcoming "Manuscripts, Images, and Biographies of Daniel Chwolson: New Details from the Archives of St. Petersburg” (2019).

4. The beginning of a Jewish prayer of blessing, used to bless those who are getting married, do work for the community, become a bar/bat mitzvah, who are ill, or on other occasions. The prayer begins Mi sheberach avoteinu . . ., "May the one who blessed our ancestors bless ..." Thanks to Rabbi Bob Freedman for this translation. - Ed.

5. As far as I know, this text has not been translated into English. 
Lithuania, giving lectures against the blood libel (Gintsburg [Günzburg] 1900, column 13).

\section{Plan for the establishment of a new university instruc- torship in Judaic Studies}

The last third of the 19th century in Germany brought dramatic changes, inter alia, the dismantling of conservative Protestant hegemony in the training of academic scholars of Judaism. Such a fundamental change was hardly an end in itself. Rather, it grew out of the new educational institutions that emerged precisely during this period, created through the program Wissenschaft des Judentums and intended for the education of would-be rabbis. These institutions modeled themselves on the external forms of the classical liberal arts university of the 19th century and cultivated the study of the history of Judaism and of Jewish literature that aptly employed the historical critical approach and, more important, was liberated from a Christian projective interpretation of Judaism. For the purposes of my study, two such institutions are important, both established with the support and participation of Abraham Geiger (1810-74), to whom Chwolson was bound by ties of personal gratitude and discipleship.

1. The Jewish Theological Seminary (Jüdisch-Theologisches Seminar Fraenckel'sche Stiftung) in Breslau was opened on August 10, 1854, with funds left by the will of the Breslau financier Jonas Fränkel. The philologist and classicist Jacob Bernays (1824-81) and the historian Heinrich Graetz (181791) occupied the central place among the professorial body of this seminary, which enjoyed the support of the Prussian government.

2. The establishment of the Higher School for the History and Study of Judaism (Hochschule für die Geschichte und Wissenschaft des Judentums) in Berlin was preceded by an initiative of several prominent Jewish scholars and officials who had founded an association ten years earlier to promote the establishment of a Jewish university. After benefactors had donated the necessary funds, the Higher School was opened on May 6, 1872, and Geiger himself held one of its most important chairs (see the literature indicated by Wiese 2005, 83-90).

Daniel A. Chwolson's archival collection has preserved interesting evidence that he planned to realize an educational project that in certain key respects clearly took as its guide the educational model estab- 
lished by Abraham Geiger. The St. Petersburg Branch of the Archive of the Russian Academy holds a lithographed letter, dated December 14, 1896 (f. 959, op. 1, ed. khr. 11, ll. 1-2), the text of which reads:

On the day of the fiftieth anniversary of my literary activity, I received from every part of our great Rus numerous telegrams and letters, in which, to my greatest joy, [the writers] expressed respect and love for me as a scholar and as a person, and which also repeatedly referred to the gratitude, which, in their opinion, they owe me. Whether I deserve all of this is not for me to judge, and I can only say that I have done what a sense of duty and justice required of me. If the fellow members of my tribe consider themselves genuinely obligated toward me and want to give me true joy, may they honor the following selfless request.

In the Eastern department of the local university there is a "Hebrew-Arabic division" - the only place in the entire Empire where Jewish studies are taught on strictly scholarly principles. Here I and my former student, now colleague K. [sic] Kokovtsov teach and read [omission in the text] biblical studies [omission in the text] Mishnah, Midrash, and various places from the Babylonian and Jerusalem Talmuds. All with strictly grammatical, philological explanations. Further: [omission in the text]. The last three works are in Arabic and Hebrew translations. In addition, works written by Jews in Arabic are read, such as the works: [omission in the text]. Also taught: the history of the Hebrew language and Hebrew literature, Hebrew paleography, as well as the Syriac language.

In sum, everything that a truly educated and learned rabbi should know is studied here.

Students in this "division" are for the most part Jews, who usually enter university with some prior knowledge of Hebrew literature. Most of these Jewish students are entirely without means, and my request is to establish a fund for one or, if possible, two scholarships for Jewish students in this division who are distinguished for their knowledge and diligence.

Currently, there are two professors in the Hebrew-Arabic division, but according to the university charter, one is designated for this division, for whom it will be impossible to teach all the above subjects should I ever have to leave the university. Although those with master's degrees in Hebrew-Arabic literature also have the right to give lectures on the aforementioned subjects, they would not be able to claim any remuneration. Therefore, it would also be highly desirable to provide for an associate professorship [dotsentura] in Jewish subjects in the He- 
brew-Arabic division through annual contributions and voluntary donations. In this way [the donors] will give intelligent Jewish communities the opportunity to be led by rabbis who are truly learned and thoroughly proficient in Jewish scholarship.

Our government, which allows the Jews to maintain Jewish religious teachers at their own expense in various educational institutions, will undoubtedly also permit the support of a Jewish instructor with the right to lecture on associate professor's level [dotsirovat'] [sic], who will also teach those Jewish subjects that are already offered. I think it not superfluous to note that most of the foreign higher educational institutions for rabbinic education are supported mainly by voluntary contributions from private individuals and communities.

Yet another story is apparent behind this document. The jubilee itself marked the fiftieth anniversary of Chwolson's literary activity, reckoned from the publication of Chwolson's first German article. It was celebrated on November 21, 1896, and was, as is evident from the preparatory materials for it from the Günzburg (Gintsburg) archive, a last-minute impromptu (RGIA, f. 1009, op. 2, d. 34; d. 38, l. 1-ob.; d. 50, 1. 3-ob.; d. 51, 1. 2-ob., and others). However, more than three weeks passed between the celebration and the date on the appeal. The text was composed, rewritten, and lithographically reproduced for distribution to a large (yet unknown) number of recipients. Everything suggests the deliberate seriousness of Chwolson's intentions; he combined two tasks in this appeal: first, to raise capital for one or two scholarships for poor Jewish students in the Hebrew-Arabic division of the Faculty of Oriental Languages, and second, more importantly, to raise capital for the establishment of an associate professorship and the corresponding strengthening of the teaching of Jewish subjects in the same division. In both cases, the stated goal was to provide educated rabbis for the communities. Although Chwolson had been expressing similar ideas at least since the 1870 s (see RGIA, f. 846, op. 1, d. 129), in this instance I believe he was trying to reproduce here the scheme behind the establishment of the Berlin "Higher School."

On December 21, 1899, the appeal was published in Voskhod [Dawn] (Khvol'son 1896), whereupon one line was added, which named the trading house "I.E. Günzburg [Gintsburg]" as the recipient and custodian of the donations. This clearly indicates the help, support, and personal involvement of Baron David Günzburg in this project. While the collection of funds to support students drew upon 
a practice widespread by that time, the establishment of an associate professorship in Jewish subjects, which would be taught by educated Jewish instructors supported by funds collected by the Jews themselves, had no precedents in the practice of imperial Russian universities. The matter, however, did not even reach the stage of submission of the project to the Ministry of Public Education.

The appeal came at the height of an intense newspaper campaign led by the editors of Voskhod in favor of creating a certain "rabbinic theological institute." The editorial on May 12, 1896 (no. 19), raised the topic: beginning with an emphatically loyal salute to the coronation of Nicholas II and Alexandra Feodorovna, the editors lamented the lack of truly educated rabbis who could "represent the Jewish subjects of Russia before Their Majesties" and concluded with a call to raise capital for the establishment of a Jewish theological institute similar to those already existing in the cultured countries of the West ("Redaktsionnaia stat'ia" 1896a). Adjoining the article was an unsigned "Letter to the editor," which vigorously repeated the same idea, and not only rich Jews but also the editors of Jewish newspapers were called to give their "mite" ("Pis'mo v redaktsiiu" 1896). Beginning right from the next issue (no. 20, dated May 19), Voskhod enthusiastically promoted the idea of such an institution as highly desirable and thereby stressed the need to collect capital for it. The topic was recurrent throughout the year 1896 in the form of editorials and surveys of "letters to the editor" (See "Redaktsionnaia stat'ia" 1896b, 1896c, 1896d, 1896e, 1896f, 1896g, 1896h, 1896i). This discussion showed that within Voskhod's readership, that is, among educated Russian-speaking Jewry, there were two parties. One supported the creation of such an institution, the other inclined to an Orthodox-conservative position and rejected the very idea of such an educational institution.

Wittingly or unwittingly, Daniel Chwolson had intervened in an issue that was controversial in the Jewish community itself. It seems quite plausible that David Günzburg, a supporter of the establishment of an institute, who had initiated the very commemoration of the Chwolson anniversary not only as a St. Petersburg academic event but also as a Jewish community celebration, proposed to Chwolson the idea to make an appeal. In this case, the naming of the trading house "I.E. Günzburg [Gintsburg]" as the custodian of donations also becomes understandable, as well as the entirely natural desire to benefit from the name and authority of the iconic Russian Jewish academic. The editorial stance of Voskhod was probably 
at odds with Günzburg's intentions, but unable to oppose him and Chwolson directly, the editors provided the pages (and evident sympathy!) for an author who wrote under the pseudonym of "the Hermit of St. Petersburg" (Peterburgskii pustynnik 1897, 1897a, 1897b, 1897c). This "Hermit" sarcastically argued against Chwolson and brought him down to the position of defending and even to a certain extent justifying his views (see his replies: Khvol'son 1897, 1897a, 1897b). Chwolson's argument was probably quite sincere. It maintained that Chwolson did not consider the associate professorship he proposed to be a replacement for a theological institute but sought only to promote the development of scholarship and the very emergence of educated rabbis. Chwolson's proposals clearly suggested the extraordinary and, for 1897 , even shocking idea of the possibility of turning over the training of future rabbis to a state university - that is, under the conditions of that time, to a manifestly Christian educational body. Yet there was an elephant in the room that was clearly visible by contemporaries, which for censorship reasons required Aesopian language. Certainly it was Chwolson's baptism in 1855 that had made his career possible, and at the same time called his right to advise the Jewish community on internal matters of Jewish religion into question.

The "Hermit" wrote in his ultimate article:

An "appeal" or "letter of request" by the venerable Professor D.A. Khvolson of his writing in the following [sic! - D.B.] explanation of this document reminded me of an old, really sad truth, which, however, one should never forget. [. . .] One can compare wholehearted love and devotion to religion with devotion and love for a beloved woman. If for any reason you gave a beloved woman a formal divorce, if from the time of the formal break with her several decades have passed, during which you have not been immersed in her joys and sorrows every day and every hour, you have not shared with her the common concerns of raising children and so on, then despite your continued respect for this woman, after such a long interruption you cannot again begin to be immersed in her life, to perceive the content and meaning of all the innermost layers of her soul, to agonize over her doubts, to be imbued with her aspirations, and to illuminate her life path. (Peterburgskii pustynnik 1897c, column 209)

The Hermit of St. Petersburg's attacks against Chwolson prompted a lengthy discussion. It resulted in readers' letters in defense of the 
professor, ${ }^{6}$ and the editors apparently considered it best to curtail both the debate between Chwolson and the Hermit, and the discussion of the institute itself ("Redaktsionnaia stat'ia" 1897a). Having given space to both polemicists in adjacent columns ("Redaktsionnaia stat'ia" $1897 \mathrm{~b}$ ), and having responded enthusiastically to the "Higher School" Geiger had created ("Redaktsionnaia stat'ia" 1897c), the editors put an end to the topic a little more than a year after the publication of the first article on the rabbinical institute ("Redaktsionnaia stat'ia" 1897d).

In this dispute both parties appealed to Geiger as the ultimate model for teaching Jewish studies according to the pattern of the European university. Chwolson's authority as the professor of Semitic languages and renowned advocate of the Jews was undeniably high, but his baptism and his proposal for teaching "Jewish disciplines" in a state Christian university clearly undermined his position. Moreover, in the context of the conservative policy pursued by the Ministry of Public Education under ministers Ivan D. Delianov 7 and Nikolai P. Bogolepov, ${ }^{8}$ Chwolson's plan was completely utopian. Nevertheless, the idea itself of establishing an institution of higher education, intended primarily for Jewish studentship and offering academic knowledge in the field of Semitic and Hebrew studies, did not die. The next attempt at its realization came in 1900-1901, undertaken by a disciple of Chwolson and a recent summa cum laude graduate of the Oriental faculty of St. Petersburg University, Naum Pereferkovich, ${ }^{9}$ in the form of a plan for individual "courses on the teaching of Semitic languages to individuals of non-Christian confessions," which, however, were not permitted to take place (RGIA, f. 733, op. 191, d. 1959; compare OR RNB, f. 183, ed. khr. 15). One should consider Baron David Günzburg's "Jewish Academy" - the first secular educational institution devoted to Judaic studies in Russia, which began its work in 1906 - the direct continuation of the idea proposed by Daniel Chwolson. Archi-

6. Khvolson's archival collection (fond) contains a copy of a letter in his defense dated April 15, 1897, sent to the editorial office of Voskhod, and signed by nine Jewish doctors and lawyers from Vitebsk (PFA RAN, f. 959, op. 1, ed. khr. 56).

7. Ivan Davydovich Delianov (1818-1897, N.S. 1898), minister of public education from 1882 till 1897/1898.

8. Nikolai Pavlovich Bogolepov (1846-1901), minister of public education from 1898 till 1901.

9. Naum (Nehemiah) Abramovich Pereferkovich (1871-1940), Semitologist, translator of the Talmud into Russian, philologist and lexicographer. 
val documents reflect the history of the organization of this academy quite well, which dates directly back to Chwolson's "Appeal" published in 1896 and merits a separate, independent study.

\section{Chwolson on Jesus and the Pharisees: The influence of the school of Abraham Geiger}

Daniel Chwolson's Nachlass, limited though it is, still preserves much that would anticipate the development of the main scholarly directions of the second half of the twentieth century. An example of this is his plan in 1900 to publish the corpus of Hellenistic Jewish literature, in the context of which Chwolson made a strong case for publishing the entire corpus of all Second Temple Hellenistic Jewish literature, a project that Leopold Cohn of Breslau, a philologist and specialist on Philo of Alexandria, would ultimately realize. The presently existing collection of German translations of Philo (Philo 1964) was the direct heir of Chwolson's unrealized project (PFA RAN, f. 959, op. 1, ed. khr. 4; ed. khr. 5).

But in order to understand the specifics of Daniel Chwolson's work as a researcher of early Christianity, one must realize the immediate context of his scholarship. The dominance of Christian theological concepts in the emerging, primarily German historical criticism was virtually unchallenged until the appearance of the so-called Wissenschaft des Judentums. This new academic discipline, modeled on the pattern of historical-critical Protestant theology, was born out of the impulse and action of several influential Jewish intellectuals, one of whom was the aforementioned Abraham Geiger. In Wissenshaft des Judentums, the Jewish minority, previously a voiceless subaltern, obtained its own voice and the possibility of reasoned argument with the help of standard means of critical scholarship, and Susannah Heschel has quite rightly called the appearance of Wissenschaft des Judentums "an uprising of the colonized." What exactly was this new discipline?

Wissenschaft des Judentums accomplished de facto the dismantling of the basic constructions of Christian anti-Judaism as a theological concept, which was fully accepted in the historical critical scholarship undertaken by Protestant scholars. Its origins are already discernible in the earliest layers of New Testament literature, but the turning point occurred at the beginning of the third century. It was in this period that the traditional Christian view and indeed

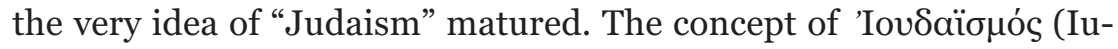


daismus), which had previously had an ethnographic meaning, "the way of life adopted by the Judeans, that is, by the present-day or former inhabitants of Judea," or a social meaning - "following the customs of the Judeans" - acquired a new Christianized meaning, formalized for the first time in its entirety by Tertullian. In the works of later Church fathers (Origen, Eusebius, Epiphanius, John Chrysostom, and others), this concept was transferred to a certain set of religious beliefs and to an order of life dictated by those beliefs (see especially Mason 2007, 471). This resulted in the concept of Judaism as essentially a religious, rather than ethnographic, phenomenon. A Christian pejorative meaning was attached to the concept of "Judaism," so radically reconceived by Christian authors: Judaism appears as a set of theological concepts, as something intellectually inferior, overshadowed and limited to the "old Covenant," whereas New Israel superseded the former one due to its superiority in theology, ethics, and universalism. During the golden age of patristics, the appropriated heritage of Judaism became the subject of intense theological reflection by authors who were for the most part unable to read the Hebrew Old Testament in the original (see the classic article, Elliott 1880), let alone to discuss contemporary Jewish texts and opinions. Examples of Christian Hebrew studies, rare in the Middle Ages and more frequent in the Reformation era, generally reflected the specific interests of individual Christian scholars, mostly the attraction of Kabbalah and esotericism, and did not engender the dismantling of the traditional Christian view of Judaism (Visscher 2014; Burnett 2012; Coudert and Shoulson 2004). Finally, even with the advent of Protestant critical scholarship in the 18th century, Judaism remained a sphere of theological manipulation: the image of Judaism was constructed as the antithesis to the Pauline - that is, "correct," "original," "undistorted" - form of Christianity as a religion that was essentially supreme in general. "Judaism" (and especially the doctrine and practice of the Pharisees who were perceived entirely through the prism of the Synoptic polemic) was constructed as the direct opposition to universalistic and non-legalistic Pauline Christianity (Gerdmar 2009). Christian theology thus constructed its imaginative "Judaism" as the quintessence of narrowness, legalism, dryness, emasculation, religious insincerity, literalism, and the loss of the spiritual understanding of the texts that had once existed and was preserved as the unique possession of the Christians; Jewish morality and Jewish mysticism were perceived a priori to be insincere, inauthentic, and flawed and then this image, sanctioned by the authority of academic theolo- 
gy, was transmitted beyond the boundaries of scholarship. Supported by the authority of Wissenschaft and the image of profound proofbased learning, in the outer context of public life this image of Judaism and fundamental Jewish concepts was in full accord with the emerging political anti-Semitism of the late 19th century and served as its "scientific" basis.

A specific feature of this theological construction was that the Christian interpreters of Judaism, with very rare exceptions, did not know and did not seek to understand the Jewish religious phenomena of the post-biblical period, and when such an interest nevertheless appeared in the second half of the 19th century, it was imbued with missionary overtones and was aimed at demonstrating the selfsufficiency of Christianity and its distinctiveness when compared to the Judaism of Jesus's contemporaries; as part of this approach the Mishnah and Gemara were studied through a specific lens, in which they were to serve as sources on Jesus and the New Testament, but the meaning and interpretation of these sources were predetermined. It should be noted that, for all the reservations about Edward Said's "Orientalism," the concept of "orientalization" works well if applied to the "inner East" of the European Jewish ethnoconfessional minority, rather than the "outer East" of the Arab and Muslim Mediterranean minority.

Two novel points should be noted in Geiger's approach. First, while taking his bearings specifically from Protestant theological scholarship as his expected audience (compare particularly the polemical afterwords to his lectures [Geiger 1865, 180-87]), Geiger deliberately rejected the unspoken assertion that Jesus was alien to the Jewish world of his day. Within this silent dogma the Synoptic consensus that the Pharisees were Jesus's topmost opponent and collective enemy was unquestioned even though the value of the Gospels as a historical source was questioned as a result of keen critical scrutiny. Nor was the accuracy of the Synoptic picture of the Pharisees questioned. Geiger presented a portrait that was directly opposite: the Pharisees in his telling became genuine reformers of Judaism, fighters for the people's cause, and opponents of the aristocratic Sadducees, who had usurped the priesthood.

Second, as Susannah Heschel rightly points out, Geiger "touched the sensitive nerve of Christian theology" (Heschel 1999, 80) when he intervened in the Leben-Jesu-Forschung, or "the quest for the historical Jesus." This academic genre, at least after David F. Strauss, became a legitimate field for the application of critical theories. Yet all 
Protestant participants of the discussion unanimously held common presumptions of Jesus as a unique figure standing above his Jewish environment and opposing it, in particular - by means of sharp polemic against the Pharisees. Geiger discussed the issue without allowances for the confessional sensitivity of his Christian opponents and portrayed Jesus as a Jew par excellence; moreover, "he was a Jew, a Pharisean Jew with a Galilean colouring - a man who joined in the hopes of his time, and who believed that these hopes were fulfilled in him. ... He did not repeal the smallest tittle of Judaism; he was a Pharisee who walked in the way of Hillel; though he did not set the most decided value upon every single external form, he yet proclaimed on the other hand, 'that not the least tittle should be taken from the Law" (Geiger 1866, 215-16). In the context of the modern "Third Quest" such a conclusion about the relationship between Jesus and the Pharisees' version of Judaism merely recapitulates the consensus and a view widely shared at least since the publication of the classic monograph by Géza Vermes [Vermes 1973]. However, in the mid-19th century such an opinion and moreover its affirmative tenor was scandalous, and the majority of Protestant critics - once again, according to Heschel's justified observation - were forced to resort to ad hominem argument since they were unable to beat Geiger in his field, that is, his expertise in Judaic religious heritage (for more detail, see Heschel 1998).

It is well known that Chwolson was attached to Geiger personally as a grateful and beloved student. Chwolson (at the time still an impoverished Jewish youngster, Joseph by name) tramped to Geiger in Breslau on foot from Riga in 1841, after he had obtained a letter of recommendation from Max Lilienthal. A year later Geiger would personally petition the Russian Ministry of Public Education to extend the period of Chwolson's stay abroad (RGIA, f. 733, op. 97, d. 51). And indeed, in his ultimate years Daniel Chwolson would dedicate his last monograph "To the Manes [sic! - D.B.] of my fatherly friend and benefactor, Rabbi Dr. Abraham Geiger, as a weak addition to and extension of his landmark studies on the Pharisees and Sadducees" (Chwolson 1910, iii). ${ }^{10}$ Chwolson proved to be one of the most consistent support-

10. The German dedication "Den Manen" reproduces in translation the Roman formula Dis manibus ("the gods, the Manes"), that is, the deified souls of ancestor-patrons. Note that Chwolson, by his formal standing a Christian (albeit of Jewish background), purposefully chose to honor his Jewish (albeit Reformist) mentor and patron by reference to the Roman pagan deities (although by the time the formula had lost any 
ers of Geiger in yet another field, in that he argued for the need to lay the foundations of New Testament interpretation on the study of Jewish sources (Chwolson 1908 [1892]).

Throughout his own academic career Chwolson championed the thesis of the affinity between Jesus and the Pharisees that Geiger had advocated (Heschel 1998, 220-21). This idea runs through all of Daniel Chwolson's works. As early as 1861 he wrote in the first version of the book on medieval accusations against the Jews:

Our Savior knew the rabbinical teachings and fought more with their arrogant representatives than with the teachings themselves. [. . .] Part of the moral teachings of the rabbis passed into Christianity, where in accordance with Christian principles the teachings became more universal. The Christian Church has even assimilated some of the rabbinic religious rites and preserved them to this day, which one must especially note of the Greek Church (Khvol'son 1861, 9-10).

The phrasing of this passage betrays the writer's care, obviously prompted by the official character of the work. Fifteen years later, in 1875, Daniel Chwolson wrote that "the teaching of Jesus, with the exception of the dogma of the Trinity, found almost nothing objectionable in the Pharisees" (Khvol'son 1875, 484), and this conclusion, among others, was the reason for the harsh criticism from Archimandrite Vitaly (Grechulevich) (A.V. [Vitalii (Grechulevich)], 1876; see Chwolson's detailed response [Khvol'son 1877, 605-9]). In the second edition of the book on medieval accusations against the Jews, Chwolson provides a comprehensive argument for this, essentially Geigerian, thesis (Khvol'son [Chwolson] 1880a, 22-39; for more detail on the same topic, see Chwolson 1908 [1892], 85-127), and returning to it in one of his last published works, Chwolson sharpened the conclusion even more:

The reason that German theologians studying the New Testament depicted the Pharisees in a completely distorted caricature was a misinterpretation of the accusatory words of Christ, addressed to the "hypocritical" Pharisees in chapter twenty-three of the Gospel of Matthew; and still to this day in all European languages the words "Pharisee" and "hypocrite" are considered synonymous; as a result of this misunderstanding,

cultic connotation). This may reflect his desire to mark it as humanistic and devoid of any religious message. 
the attitude of the Pharisees toward Jesus Christ is drawn in the wrong light. [. . .] The attitude of the Pharisees toward Christ was undoubtedly amicable, and . . . His teaching in no way contradicts the teaching of the best and most noble men of the Jewish people. German theologians, however, distorted and interpreted in the worst light everything found in the Synoptic Gospels in favor of this view; they even interpreted the Pharisees' friendly warning to Christ about the danger threatening him from His enemies as a hostile action against him. [. . .] There never were fundamental points of contention between Christ and the Pharisees [emphasis mine - D.B.]; there were only minor disagreements, like those that have occurred by the hundreds, even thousands, among rabbis of all time (Khvol'son 1911, 16-18).

In the 19th century this thesis sounded revolutionary, but in the perspective of the development of scholarship one can say that Chwolson anticipated the revolution that occurred from the 1950s to the 1970s, when the history of Second Temple Judaism, its literature, religious practices, and the social structures of the life of the Jews in Palestine and the Diaspora became the main context for the study of early Christianity.

The works of Daniel Chwolson aimed at the refutation of the blood libel are unquestionably scholarly studies, although undertaken with a polemical public purpose. Contemporaries noted similar potential in Chwolson's works on the Pharisees and Jesus (for example, Malis 1906), and although their content to a certain extent anticipates mainstream scholarly thought in the second half of the 2oth century, in general one can say that in the context of the 19th century and for the contemporaries of Chwolson himself, the examples considered above fit into a framework of public activity aimed at protecting the Jewish minority of the Russian Empire that was by no means limited to refuting the blood libel. Such measures should include the unsuccessful attempt to establish an associate professorship in Jewish subjects at St. Petersburg University. No less important - inspired by the example of his teacher Abraham Geiger and following the academic path of Wissenschaft des Judentums - Daniel Chwolson worked fruitfully to overcome Christian theological projections in the academic study of Judaism. 


\section{References}

Otdel rukopisei Rossiiskoi natsional'noi biblioteki [Manuscript Department of the Russian National Library] (hereafter, OR RNB), f. 183 Gintsburg D.G., ed. khr. 15.

OR RNB, f. 183 Gintsburg D.G., ed. khr. 51.

Sankt-Peterburgskii filial arkhiva rossiiskoi akademii nauk [St. Petersburg Branch of the Archive of the Russian Academy of Sciences] (hereafter, PFA RAN), f. 959, op. 1, ed. khr. 4.

PFA RAN, f. 959, op. 1, ed. khr. 5 .

PFA RAN, f. 959, op. 1, ed. khr. 56.

Rossiiskii gosudarstvennyi istoricheskii arkhiv [Russian State Historical Archive] (hereafter, RGIA), f. 733, op. 97, d. 51.

RGIA, f. 733, op. 191, d. 1959.

RGIA, f. 846, op. 1, d. 129.

RGIA, f. 1009, op. 2, d. 34 .

RGIA, f. 1009, op. 2, d. 38.

RGIA, f. 1009, op. 2, d. 50.

RGIA, f. 1009, op. 2, d. 51.

A.V. [Vitalii (Grechulevich), arkhimandrit (archimandrite)]. 1876. "Posledniaia paskhal'naia vecheria Iisusa Khrista i den' Ego smerti” [The last paschal supper of Jesus Christ and the day of his death]. Strannik (November): 97-126; (December): $185-289$.

Burnett, Stephen G. 2012. Christian Hebraism in the Reformation Era (150o-166o): Authors, Books, and the Transmission of Jewish Learning. Leiden: Brill.

Chwolson, D. 1901. Die Blutanklage und sonstige mittelalterliche Beschuldigungen der Juden: Eine historische Untersuchung nach den Quellen. Frankfurt: Kauffmann.

---. 1908 (1892). Das letzte Passamahl Christi und der Tag seines Todes nach den in Übereinstimmung gebrachten Berichten der Synoptiker und des Evangelium Johannis nebst Schluss und Anhang... Anastatischer Neudruck der Ausgabe von 1892, Mémoires de l’Académie impériale des sciences de St.-Pétersbourg, VIIe serie, XLI, no. 1. St. Petersburg.

---. 1910. Beiträge zur Entwicklungsgeschichte des Judentums von ca. 400 v. Chr. bis ca. 1000 n. Chr. Leipzig: Haessel.

Coudert, Allison P., and Jeffrey S. Shoulson. 2004. Hebraica Veritas? Christian Hebraists and the Study of Judaism in Early Modern Europe. Philadelphia: University of Pennsylvania Press.

Elliott, C.J. 1880. "Hebrew Learning among the Fathers." In Dictionary of Christian Biography, edited by W. Smith and H. Wace, 2:851-72. London: John Murray.

Geiger, Abraham. 1865. Das Judenthum und seine Geschichte. Vol. 1, Abteilung: Bis zum Zerstörung des zweiten Tempels. Breslau: Schletter.

---. 1866. Judaism and Its History. Vol. 1, Closing with the Destruction of the Second Temple. Translated from the German by Maurice Mayer. New York: Thalmessinger \& Cahn, 1866.

Gerdmar, Anders. 2009. Roots of Theological Anti-Semitism: German Biblical Interpretation and the Jews, from Herder and Semler to Kittel and Bultmann. Leiden: Brill. 
Gintsburg [Günzburg], David G. 1900. "D.A. Khvol'son (Okonchanie)" [D.A. Khvol'son (Conclusion)]. Voskhod 3: col. 13-14.

Heschel, Susannah. 1998. Abraham Geiger and the Jewish Jesus. Chicago: University of Chicago Press.

---. 1999. "Revolt of the Colonized: Abraham Geiger's Wissenschaft des Judentums as a Challenge to Christian Hegemony in the Academy.” New German Critique 77: 6185 .

Khvol'son, Daniil A. 1861. O nekotorykh srednevekovykh obvineniiakh protiv evreev (Istoricheskoe issledovanie po istochnikam) Soch. professora evreiskago i siriiskago iazykov i slovesnosti pri Sankt-Peterburgskii universitete D.A. Khvol'sona [On certain medieval accusations against the Jews (Historical investigation based upon sources) compiled by D.A. Khvol'son, professor of Hebrew and Syriac languages and literature at St. Petersburg University]. St. Petersburg: Tipografiia Shtaba Otdel'nago korpusa vnutrennei strazhi.

-_-. 1875. "Posledniaia paskhal'naia vecheria Iisusa Khrista i den' Ego smerti” [The last paschal supper of Jesus Christ and the day of his death]. Khristianskoe chtenie 9-10: 430-88.

---. 1877. "Posledniaia paskhal'naia vecheria Iisusa Khrista i den' Ego smerti" [The last paschal supper of Jesus Christ and the day of his death]. Khristianskoe chtenie 1112: $557-610$.

---. 1879. Upotrebliaiut li evrei khristianskuiu krov'? Rassuzhdenie D.A. Khvol'sona, ordinarnago professora evreiskago, khaldeiskago i siriiskago iazykov pri Sankt-Peterburgskom universitete, ordinarnago professora pri Sankt-Peterburgskoi dukhovnoi akademii [Do Jews use Christian blood? A discussion by D.A. Khvol'son, professor of Hebrew, Chaldean, and Syriac languages at St. Petersburg University, professor at St. Petersburg Theological Academy]. 2nd edition, revised and supplemented by three appendices. St. Petersburg: Tipografiia Tsederbauma i Gol'denbliuma.

---. 1880 [censorship date]. O mnimoi zamknutosti evreev [On the supposed insularity of the Jews]. St. Petersburg: Tipografiia Tsederbauma i Gol'denbliuma.

---. 1880a. O nekotorykh srednevekovykh obvineniiakh protiv evreev: Istoricheskoe issledovanie po istochnikam D. Khvol'sona, ordinarnago professora evreiskago, khaldeiskago i siriiskago iazykov pri Sankt-Peterburgskom universitete chlen korpusa Akademii nauk i proch. [On certain medieval accusations against the Jews: Historical investigation based upon sources by D. Khvol'son, professor of Hebrew, Chaldean, and Syriac languages at St. Petersburg University, member of the corps of the Academy of Sciences, and so on]. 2nd edition, sovershenno pererab [completely revised]. St. Petersburg: Tipografiia Tsederbauma i Gol'denbliuma.

--_. 1896. "Vozzvanie professora Daniila Abramovicha Khvol'sona" [An appeal by Professor Daniel Abramovich Khvol'son]. Nedel'naia khronika Voskhoda 52: col. 137072.

---. 1897. "Pis'mo v redaktsiiu" [Letter to the editor]. Nedel'naia khronika Voskhoda 3: col. 43 .

---. 1897a. "O evreisko-arabskom razriade" [On the Hebrew-Arabic department]. Nedel'naia khronika Voskhoda 5: col. 109-11.

---. 1897b. "O ravvinskom voprose" [On the rabbinic question]. Nedel'naia khronika Voskhoda 6: col. 141-43.

---. 1911. "Vozrazheniia protiv lozhnogo mneniia, budto Iisus Khristos v deistvitel'nosti ne zhil" [Objections to the false opinion that Jesus Christ never actually lived]. Khristianskoe chtenie 1: 3-22. 
-—-. 1912. Upotrebliaiut li evrei khristianskuiu krov'? Rassuzhdenie A.D. [sic! - D.B.] Khvol'sona, ordinarnago professora evreiskago, khaldeiskago i siriiskago iazykov pri Sankt-Peterburgskom universitete, ordinarnago professora pri Sankt-Peterburgskoi dukhovnoi akademii [Do Jews use Christian blood? A discussion by D.A. Khvol'son, professor of Hebrew, Chaldean, and Syriac languages at St. Petersburg University, professor at St. Petersburg Theological Academy]. 3rd edition. Kyiv: Tipografiia R.K. Lubkovskogo.

Malis, I. 1906. Kto vinoven $v$ smerti Spasitelia? Po povodu raboty D.A. Khvol'son "Posledniaia paskhal'naia vecheria Iisusa Khrista i den' ego smerti” [Who is guilty of the Savior's death? Concerning the work "The last paschal supper of Jesus Christ and the day of his death" by D.A. Khvol'son]. Odessa: Tipografiia Izdatel'.

Mason, Steve. 2007. “Jews, Judaeans, Judaizing, Judaism: Problems of Categorization in Ancient History.” Journal for the Study of Judaism 38: 457-512.

Peterburgskii pustynnik [St. Petersburg hermit]. 1897. "Pis'mo v redaktsiiu" [Letter to the editor]. Nedel'naia khronika Voskhoda 1-2: col. 6-8.

- - . 1897a. "Pis'mo v redaktsiiu" [Letter to the editor]. Nedel'naia khronika Voskhoda 4: col. 78-80.

- - . 1897b. "Pis'mo v redaktsiiu" [Letter to the editor]. Nedel'naia khronika Voskhoda 7: col. 172-74.

- - . 1897c. "Pis'mo v redaktsiiu" [Letter to the editor]. Nedel'naia khronika Voskhoda 8 (February 23): col. 206-9.

Philo of Alexandria. Die Werke in deutscher Übersetzung. Vol. 7. Edited by Leopold Cohn, Isaak Heinemann, Maximilian Adler, and Willy Theiler. Berlin: De Gruyter, 1964.

"Pis'mo v redaktsiiu" [Letter to the editor]. 1896. Nedel'naia khronika Voskhoda 19 (May 12): col. 508-9.

“Redaktsionnaia stat'ia” [Editorial]. 1896a. Nedel'naia khronika Voskhoda 19 (May 12): col. 506-8.

“Redaktsionnaia stat'ia” [Editorial]. 1896b. Nedel'naia khronika Voskhoda 20 (May 19): col. 530-31.

"Redaktsionnaia stat'ia" [Editorial]. 1896c. Nedel'naia khronika Voskhoda 21 (May 26): col. $555-58$.

“Redaktsionnaia stat'ia” [Editorial]. 1896d. Nedel'naia khronika Voskhoda 22 (June 2): col. 580 .

“Redaktsionnaia stat'ia” [Editorial]. 1896e. Nedel'naia khronika Voskhoda 26 (June 20): col. 677-79.

“Redaktsionnaia stat'ia” [Editorial]. 1896f. Nedel'naia khronika Voskhoda 27 (July 7): col. 698-702.

“Redaktsionnaia stat'ia” [Editorial]. 1896g. Nedel'naia khronika Voskhoda 33 (August 18): col. $850-850$.

“Redaktsionnaia stat'ia" [Editorial]. 1896h. Nedel'naia khronika Voskhoda 36 (September 8): col. 932-33.

"Redaktsionnaia stat'ia” [Editorial]. 1896i. Nedel'naia khronika Voskhoda 37 (September 15): col. 954-56.

“Redaktsionnaia stat'ia” [Editorial]. 1897. Nedel'naia khronika Voskhoda 18: col. 498-501.

“Redaktsionnaia stat'ia” [Editorial]. 1897a. Nedel'naia khronika Voskhoda 18: col. 498-501.

"Redaktsionnaia stat'ia” [Editorial]. 1897b. Nedel'naia khronika Voskhoda 19: col. 541-42.

"Redaktsionnaia stat'ia” [Editorial]. 1897c. Nedel'naia khronika Voskhoda 23: col. 665-67. 
"Redaktsionnaia stat'ia" [Editorial]. 1897d. Nedel'naia khronika Voskhoda 24: col. 678-80. Vermes, Géza. 1973. Jesus the Jew. London: SCM.

Visscher, Eva De. 2014. Reading the Rabbis: Christian Hebraism in the Works of Herbert of Bosham. Leiden: Brill.

Wiese, Christian. 2005. Challenging Colonial Discourse: Jewish Studies and Protestant Theology in Wilhelmine Germany. Translated from the German by Barbara Harshav and Christian Wiese. Leiden: Brill. 